\title{
A face oculta da caridade: linhas de força e de fratura no discurso midiático do bem*
}

\section{RESUMO}

Discutindo mais profundamente o conceito de cidadania e sua apropriação pela mídia como algo a ser 'oferecido' às minorias, este artigo analisa as condições materiais e simbólicas que estão por trás de uma comunicação baseada na discursificação do bem. Buscamos mostrar como linhas de força se perpetuam à medida que a autonomia das minorias vai sendo progressivamente minada por um discurso de docilização, que congela a alteridade na posição permanente de devedor. Neste sentido, procuramos discutir o sentido da dominação e os mecanismos tácitos de que faz uso para manter e validar o discurso hegemônico.

\section{PALAVRAS-CHAVE}

empoderamento discursivo

humilhação social

cidadania

\section{ABSTRACT}

Discussing more thoroughly the concept of citizenship and its appropriation by mass media like something to be "offered" to the minorities, the present article analyses the material and symbolical conditions which are behind a communication system based upon the discursification of good. We try to show how lines of force perpetuate themselves in the same measure as the minorities' autonomy is progressively being undermined by a docilization discourse, which congeals alterity into the permanent debtor position. In this sense, we seek to discuss the meaning of domination and the tacit mechanisms it uses in order to maintain and validate the hegemonic discourse.

\section{KEY WORDS}

discursive empowerment

social humiliation

citizenship

\section{Luciane Lucas}

Professora do Mestrado em Comunicação e Práticas de Consumo da ESPM/SP/BR

llucas@espm.br

\section{Tânia Hoff}

Professora do Mestrado em Comunicação e Práticas de Consumo da ESPM/SP/BR

thoff@espm.br

\section{A outra face do "dom" e a humilhação social por trás da discursificação do bem}

O termo cidadania tem sido permanentemente empregado na mídia - e, na seqüência, banalizado em formas múltiplas de comunicação - como se encerrasse valores ou condições transferíveis a outros indivíduos. Ou seja, o uso do termo parece sugerir sempre algo que pudesse ser conferido a outrem ou que definisse um modelo de comportamento, uma postura diante do mundo. Na prática, entretanto, esta idéia - legitimada no senso comum e em algumas correntes do conhecimento - não se sustenta.

De modo mais profundo, o pensamento de Hannah Arendt, que adotamos no presente artigo, apresenta a cidadania como diretamente relacionada às condições de ação e palavra de que um sujeito pode ser portador. Na impossibilidade de ser protagonista de sua história ou da história de seu grupo, torna-se inviável a condição de cidadão. Assim, um indivíduo não é cidadão apenas porque contribuiu solidariamente para reduzir o sofrimento de outrem, como usualmente a mídia reforça a todo momento, mas porque tem condições asseguradas ele mesmo de expressar-se, de interferir no modelo de constituição de sentido em que ele está socialmente inserido, de agir sobre suas condições materiais e simbólicas de existência. Ou seja, "cidadão é quem, em companhia de outros cidadãos, toma iniciativas e anuncia iniciativas por meio da voz, por meio de palavras. O cidadão é quem inicia, em companhia de outros iniciadores com quem conversa" (Gonçalves Filho, 2007, p.199).

Esta aptidão própria do cidadão para ser iniciador revela a imprescindibilidade de poder escolher suas próprias soluções e intervir no próprio destino, a despeito das condições externas desfavoráveis e do ambiente de dominação em que possa estar inserido. Isso mostra que a cidadania não é uma condição que possa ser repassada, como um presente, ou possa ser conferida como uma espécie de aprendizado. Isso não significa, entretanto, que ela não possa ser impedida, à medida que relações de dominação tendem a suprimir os ingredientes básicos para sua constituição: estamos falando da palavra e também da ação que o empoderamento discursivo confere. Assim, ser iniciador pressupõe a capacidade de poder intervir nos automatismos sociais (Gonçalves Filho, 2007) e recriar história, o que só é possível quando estão asseguradas estas condições de expressão e ação.

A cidadania, portanto, pressupõe ter para si esta ação e palavra e oferecer ao outro as mesmas condições. Significa, em última análise, reunir condições para a resistência sempre que as estruturas de poder consolidem domínios de saber e práticas sociais que naturalizem a 
hegemonia. A resistência, neste caso, representa uma aposta naquilo que Foucault (1994) chama linhas de fratura, capazes de fissurar as linhas de força que sustentam o poder constituído.

\section{A satisfação destas necessidades básicas não reverte a posição econômico-simbólica desigual e ancestralmente humilhante a que certas minorias são submetidas pelo arranjo capitalista.}

Contudo, a busca por uma posição melhor nesta disputa de forças - rumo à emancipação social e a certa neutralização da dominação - esbarra freqüentemente na legitimação de um saber hegemônico que só faz confirmar os valores dominantes da produção simbólica. Estamos falando de perspectivas e máximas que norteiam um dado contexto social e que passam a fazer parte da agenda tanto daqueles que integram os centros de produção de significado (Bauman, 1999), como daqueles que, excluídos, buscam dela participar. Tais domínios de saber são amplamente naturalizados, de forma que esta lente 'dominante', alicerce de valores e perspectivas da sociedade de consumo, apaga os traços do jogo de produção de verdade que lhe é intrínseco. Embora aprendamos com Foucault (1979) que o poder seja móvel e não se cristaliza em uma única posição, é fundamental não esquecer que o conhecimento, ao ser "fundamentalmente interessado, produzido como acontecimento do querer e [determinante de um] efeito de verdade", produz enunciados e perspectivas já comprometidos com a dinâmica de forças. E, como tal, com a perpetuação das condições desiguais de embate. Se, como nos adverte a genealogia foucaultiana, "o indivíduo é uma produção do poder e do saber", pode-se dizer que suas condições de visibilidade e ação dependem da convergência com os valores dominantes.

Um destes valores que vale a pena analisar é a caridade. Comprometida com uma economia da dádiva - e assim reproduzindo, no cenário contemporâneo, as posições desiguais do modelo capitalista de produção -, a caridade, não raro, engessa indivíduos e minorias em posições subalternas. Naturalmente, não se trata, aqui, de uma argumentação em oposição à caridade, mas de uma análise crítica de sua face oculta, de modo a evidenciar os pontos em que ela interfere na condição de cidadania de indivíduos e grupos. Se a discursificação da caridade na mídia se baseia na idéia de que o agente consolida sua posição de cidadão sempre que ajuda as classes mais pobres ${ }^{1}$, cabe observar que: 1) sua ação raramente se compromete com mudança de quadro social, cristalizando o outro na posição de quem nada tem a oferecer; 2) dentro de uma economia do dom, sua ação não equivale aos impactos econômicos, sociais e culturais que seu modelo de consumo usualmente sustenta.

Ao mesmo tempo, a mesma discursificação da caridade costuma sinalizar que o outro, receptor da dádiva, pode adquirir o status de cidadão pela posse de coisas que lhe são dadas pelo agente - comida, água, luz, escola - como se estas coisas pudessem transformar magicamente indivíduos excluídos em protagonistas sociais. O que gostaríamos de ressaltar, aqui, é que a satisfação destas necessidades básicas não reverte a posição econômico-simbólica desigual e ancestralmente humilhante a que certas minorias são submetidas pelo arranjo capitalista. Como nos lembra Paul Singer ao descrever a desigualdade inerente ao capitalismo, "os ganhadores acumulam vantagens e os perdedores acumulam desvantagens nas competições futuras" (Singer, 2002, p.9).

Para entender melhor esta relação entre caridade e poder, devemos primeiramente nos reportar ao conceito de dom enunciado por Marcel Mauss - e, posteriormente, analisado pela lente marxista de Maurice Godelier ${ }^{2}$. Segundo Mauss, o dom pressupõe três obrigações: dar, receber e restituir. Estas etapas seriam inerentes a todo tipo de trocas simbólicas e desta forma podemos depreender que, na sociedade ocidental, elas reproduzem os sistemas de valores e de hierarquia presentes nas relações sociais. Mauss concentrou sua atenção na terceira etapa - a restituição -, entendendo que existia, neste ponto, um enigma a ser decifrado: "que força há na coisa que se dá que faz com que o donatário a restitua?" (Godelier, 2001, p.14). Mais adiante, Godelier vai retomar esta pergunta e buscar uma resposta para o enigma do dom. Mais que isso: vai levantar questões a ele relacionadas que vão lançar as bases de uma reflexão política sobre o sentido da dádiva, já que o dom confere e distribui poderes no sistema de partilha.

Godelier demonstra que o dom não se desvincula de uma dinâmica de forças; ao contrário, pode confirmá-la à medida que a dádiva "não é apenas uma maneira de partilhar o que se tem, mas também uma maneira de combater com o que se tem" (2001, p.15). O ato de dar estabelece uma relação desigual sempre que o agente considera que o receptor não tem nada a oferecer, desprovido que é - segundo os parâmetros do agente, é claro - de condições mínimas de troca. Neste aspecto, doar implica uma relação paradoxal em que se estabelecem dois tipos de vínculo - uma relação de solidariedade, "pois quem dá partilha o que tem e quiçá o que é" (Godelier, 2001, p.23), e, simultaneamente, uma relação de superioridade que consolide uma história de dependência. Novamente é Godelier quem nos esclarece esta tênue distância entre a dádiva e a violência simbólica: 
Dar parece instaurar assim uma diferença e uma desigualdade de status entre doador donatário, desigualdade que em certas circunstâncias pode se transformar em hierarquia: se esta já existisse entre eles antes do dom, ele viria expressá-la e legitimá-la ao mesmo tempo. Portanto, dois movimentos opostos estariam contidos em um único e mesmo ato. $\mathrm{O}$ dom aproxima os protagonistas porque é partilha e os afasta socialmente porque transforma um deles em devedor do outro. Pode-se divisar o formidável campo de manobras e de estratégias possíveis contido virtualmente na prática do dom e a gama de interesses opostos que ele pode servir [...] Ele pode ser, ao mesmo tempo ou sucessivamente, ato de generosidade ou ato de violência, mas nesse caso de uma violência disfarçada de gesto desinteressado, pois se exerce por meio e sob a forma de uma partilha (Godelier, 2001, p.23).

Neste sentido, podemos enxergar melhor a face oculta da caridade e o quanto ela pode se distanciar da idéia de cidadania, calcada, necessariamente, no ato de conferir voz em detrimento do silêncio típico das relações de dependência e hierarquia. A exclusão simbólica que o dom - em condições desiguais de partilha - pode legitimar evidencia a atenção necessária para distinguir a dádiva que engessa o indivíduo em uma posição subalterna das iniciativas de empoderamento comprometidas com o estímulo à condição de resposta do sujeito. A desigualdade que orbita em torno de muitas das relações entre indivíduos e grupos, tem origem política e, por desdobramento, configura-se como diferença econômica e cultural (Gonçalves Filho, 2004, p.36).

Deste modo, a invisibilidade social das minorias e o silêncio a que são submetidas confirmam sua desconfortável posição. Sem palavra e sem condição de agir por si mesmo, o indivíduo que é sempre alvo do dom fica "publicamente congelado na figura do carente, alguém de quem cabe nos ocuparmos e que estaria impedido, ele próprio, de ocupar-se de alguém" (2004, p.43). A condição política de humanidade se confirma sempre que há troca de dons. Isso significa que as posições de dar e receber devem ser permanentemente revezadas, se o que se tem em mente é o resgate efetivo da condição de cidadania (Gonçalves Filho, 2004). Do contrário, o dom, tão necessário nas relações sociais, e evocativo que é do sentido de humanidade nas trocas culturais, redundará em violência simbólica.

Assim, se desejamos efetivamente suplantar as condições desiguais que o modelo hegemônico de mundo naturaliza, é preciso ir além da caridade e estimular a emancipação social de grupos a partir do empoderamento discursivo e da autonomia econômica. É preciso estimular a voz e as próprias escolhas, bem como reforçar a condição de ser o protagonista das próprias alternativas - como veremos, mais adiante, com a construção coletiva de cisternas rurais pela Articulação do Semi-árido Brasileiro (ASA), reunião de inúmeras entidades que trabalham a convivência das famílias nordestinas com os dilemas da seca. Este e outros casos evidenciam a importância de uma aposta na autonomia simbólica e econômica.

Esta autonomia, por sua vez, se fundamenta no fortalecimento dos grupos sociais. Trata-se, em última análise, de ampliar suas condições de interferência nos atributos de valor que balizam a cultura contemporânea, sabendo-se que ela sempre será o produto de um embate de forças. Diferente da caridade no seu aspecto de dependência, os esforços de empoderamento devem se comprometer com a construção de novas linhas de visibilidade e enunciação (Deleuze, 1994). Deste modo, pode-se alterar o quadro de invisibilidade política destas minorias e da humilhação social a que são freqüentemente submetidas.

\section{Podemos enxergar melhor a face oculta da caridade e 0 quanto ela pode se distanciar da idéia de cidadania, calcada, necessariamente, no ato de conferir voz em detrimento do silêncio típico das relações de dependência e hierarquia.}

Onde se busca fomentar a cidadania, a dominação deve sofrer duros golpes. Naturalmente, que o poder não se resume a uma das pontas, de modo que falar em dominação demanda não esquecer que os dominados também podem ressignificar os códigos dominantes. Como nos adverte Foucault, "os poderes se exercem em níveis variados e em pontos diferentes da rede social", de modo que "não estão localizados em nenhum ponto específico da estrutura social", mas, sim, "funcionam como uma rede de dispositivos ou mecanismos a que nada nem ninguém escapa" (Machado, In: Foucault, 1979, p. XIV). Ainda assim, mesmo diante desta dinâmica de forças que garante que o jogo não está dado a priori, é preciso não perder de vista que a dominação é a consolidação natural de uma desigualdade subjacente. Logo, se à cidadania compete resgatar a igualdade como condição política (Gonçalves Filho, 2004), o trabalho começa por estimular a troca de papéis na configuração do dom, lançando por terra a concepção etnocêntrica de 
valores daquele que dá, bem como estimular palavra e ação. Palavra que liberta a voz. Ação que restitui o papel até então perdido de protagonista.

\section{Discutindo o sentido de cidadania: em busca da ação e da palavra perdidas}

Muitas são as definições de cidadania. Algumas mais vagas, que não definem bem quem é o cidadão - o agente, com suas condições garantidas de intervenção no mundo, ou o recebedor, uma vez que os direitos mínimos tenham sido assegurados. Fato é que o poder, em seu contínuo processo de deslocamento, acaba por definir onde os ingredientes iniciais podem ser encontrados. Voz e capacidade de ação quase sempre se manifestam do lado dominante. Talvez seja por isso que Pedro Demo $(1995$, p.6) fale a respeito de dois tipos de cidadania - e que bem nos auxiliam a pensar o lugar da mídia na sociedade brasileira. Uma delas é denominada cidadania tutelada "que a direita (elite econômica e política) cultiva ou suporta, a saber, aquela que se tem por dádiva ou concessão de cima" e que tem como resultado "a sua negação/repressão" e "a reprodução indefinida da sempre mesma elite histórica". Já o segundo tipo é denominado cidadania assistida:

[...] expressa a forma mais amena de pobreza política, porque já permite a elaboração de um embrião da noção de direito, que é o direito à assistência, integrante de toda democracia. Entretanto, ao preferir assistência à emancipação, labora também na reprodução da pobreza política, à medida que, mantendo intocado o sistema produtivo e passando ao largo das relações de mercado, não se compromete com a necessária equalização de oportunidades. $\mathrm{O}$ atrelamento da população a um sistema de benefícios estatais é seu engodo principal. Maquina a marginalização social. Não se confronta com ela (Demo, 1995, p.6).

Nesse sentido, Frigotto (1992) pondera que, embora seja senso comum mencionar que todo brasileiro é um cidadão, trata-se de uma forma de esconder a cidadania ausente, que se manifesta por meio dos elevados índices de analfabetismo e de pobreza, de má distribuição de renda, de mortalidade infantil, de doenças endêmicas, de subnutrição, de violência etc. A cidadania tutelada parece ainda suplantar a assistida em território nacional quando se considera o imaginário da população em geral acerca da miséria e da pobreza. Segundo Demo são requisitos fundamentais da cidadania de fato:

[...] consciência crítica, raciocínio lógico, responsabilidade individual e coletiva, habilidades de tomar decisões e iniciativas, de aceitar e conviver com diferentes opiniões e pontos de vista, de criar alternativas de soluções. Enfim, estar preparado para a autonomia e a responsabilidade para a participação efetiva nas transformações necessárias ao progresso do país (2007, p.79-80).

A cidadania, porém, só pode se realizar mesmo em um cenário propício à experiência de humanidade ${ }^{3}, \mathrm{o}$ que pressupõe igualdade política dos pares para que cada um possa interagir em suas plenas condições de protagonismo. A cidadania, portanto, acontece necessariamente em espaços de relação. Isso significa que ela só se manifesta quando ambas as partes mantém as condições de doação e recebimento, revezando posições. Ou seja, a cidadania, se não é partilhada, não acontece. É na ambiência das relações, com suas afecções e intempéries, com sua proximidade desconcertante e seu revezamento de vozes, que a cidadania pode se manifestar, se considerarmos que "o que há de mais íntimo na vida de cada homem só pode encontrar resposta na estrutura social" (Bosi, 2003, p.179). Não se pode ser cidadão à distância. Nem fora do campo de visão de outros homens. Este fato, aliás, ultrapassa a própria discussão sobre o conceito de cidadania (embora a atinja visceralmente), já que não há nada que o homem faça e que adquira sentido na ausência de outros semelhantes. A valoração de todas as ações humanas depende invariavelmente do olhar e da percepção de seus pares. Neste ponto, Hannah Arendt nos mostra porque a invisibilidade política é o mal maior a que se pode submeter um indivíduo: "todas as atividades humanas são condicionadas pelo fato de que os homens vivem juntos; mas a ação é a única que não pode sequer ser imaginada fora da sociedade dos homens [...]" (2007, p. 31). E ela prossegue evidenciando porque ação e palavra são os ingredientes básicos para a cidadania e porque não se pode ser cidadão sozinho: "só a ação é prerrogativa exclusiva do homem; nem um animal nem um deus é capaz de ação, e só a ação depende inteiramente da constante presença de outros" (Arendt, 2007, p.31).

Na contramão do que parece óbvio, toda a discussão sobre cidadania tem sido submetida a uma atmosfera permanente de espetacularização. A mídia não é a única a fazê-lo, se considerarmos o discurso das empresas (autodenominadas cidadãs) ${ }^{4}$, do próprio governo e de várias organizações não-governamentais. No decurso desta crescente banalização do sentido político da cidadania, há um progressivo esvaziamento de seu significado, como se esta palavra integrasse a lógica das transações de bens, coisificando-se e podendo ser magicamente oferecida às pessoas - tanto àquelas que nunca conferiram igualdade política aos seus semelhantes e que foram tocadas pelo sentimento temporário de solidariedade, como aquelas que, por razões históricas, foram destituídas de visibilidade e voz.

Mas só é possível falar em cidadania se há aumento do espaço discursivo - ou seja, de um espaço que reconheça na alteridade os direitos de palavra e ação (Arendt, 2007). Isso significa, é claro, reconhecer tem- 
poralidades diversas, modelos de mundo alternativos, conhecimentos outros que escapem aos domínios de saber que preponderam no formato hegemônico por nós digerido e re-produzido. É preciso suscitar uma "sociologia das ausências", como nos propõe Boaventura de Sousa Santos, depurando do conhecimento toda a carga de reprodução do status quo a que ele tem servido. Ou mais ainda, como o próprio Boaventura sugere, "necessitamos de um novo modo de produção de conhecimento" (Santos, 2007), cujas prerrogativas se fundamentem em um novo modo de olhar a realidade e de obter dela condições efetivas de emancipação social. Boaventura (2007) nos adverte quanto ao modelo de monocultura que se espraia, como praga, em vários aspectos de nossa interação com o mundo, podendo, por conseqüência, inviabilizar o exercício da cidadania: monocultura do saber - ao se presumir um só modelo de produção de conhecimento -, monocultura do tempo linear, monocultura de naturalização das diferenças, para citar algumas.

\section{No decurso desta crescente} banalização do sentido político da cidadania, há um progressivo esvaziamento de seu significado, como se esta palavra integrasse a lógica das transações de bens, coisificando-se e podendo ser magicamente oferecida às pessoas.

Uma análise mais detalhada sobre a lente que usamos para falar em transformação social e cidadania nos mostra que o modelo de conhecimento de que partimos para amparar diagnósticos e ações já contém em si o antídoto à mudança. Como falar em ação e palavra, se o modelo de conhecimento hegemônico silencia soluções próprias e saberes alternativos de comunidades e grupos minoritários? Como valorizar a voz se os sentidos foram previamente estabelecidos? Como estimular a ação de minorias quando os ritmos e os objetivos a que são submetidas não são reconhecidos como seus? Estas e outras questões nos mostram que a emancipação social começa, necessariamente, com um destronamento das verdades consolidadas nas linhas de força do saber ocidental. O que se torna mais fácil se lembrarmos que a verdade é sempre produto de um jogo de forças (Foucault, 1997); sempre um efeito, uma perspectiva, nunca uma máxima.

Neste sentido, a comunicação tanto pode funcionar como um mecanismo legitimador das linhas de força e, como tal, dos discursos e saberes dominantes, como pode, na contramão, contribuir para a construção de novas formas de ver e fazer. Assim, a comunicação, em um aspecto contra-hegemônico, adquire outras funções: 1. criar visibilidade e circulação de saberes alternativos; 2. valorizar outros ritmos e rituais nas relações sociais e nas trocas simbólicas que as integram; 3 . criar condições de troca que permitam revezamento de papéis (doação e recebimento) entre agentes sociais, de modo a não sustentar relações desiguais e de dominação. Estas e outras funções só são possíveis diante de um novo modelo de comunicação, entendido não como instrumento de poder e convencimento, mas como um processo de construção de laços e empoderamento de minorias. Só assim podemos falar em fratura no modelo hegemônico de mundo e de constituição de sentido.

\section{Comunicação e Cidadania: da espetacularização da caridade na mídia ao empoderamento discursivo das minorias}

Duas perspectivas de análise da comunicação se nos apresentam de modo enfático quando consideramos as relações entre cidadania e caridade: aquela da comunicação midiática que permite discutir o esvaziamento do conceito de cidadania apresentado na mídia e aquela processual e contra-hegemônica que fomenta as reflexões a respeito da construção e do exercício da cidadania.

Num contexto em que a comunicação funciona como um mecanismo legitimador das linhas de força é que se questiona a atuação da mídia tanto na divulgação de campanhas de solidariedade quanto na de seus resultados: abordar problemas sociais como se fossem problemas de caridade pouco ou nada contribui para a sua solução ou para o exercício da cidadania. Sensibilizar para a doação de brinquedos, dinheiro, agasalho ou livro e divulgar as cifras alcançadas é o que a mídia tem feito mais comumente.

Os meios de comunicação constituem uma das principais fontes de informação na sociedade brasileira: convivemos com tanta familiaridade com as idéias e imagens neles veiculadas que as aceitamos como verdade e as utilizamos para guiar nossas decisões e escolhas cotidianas. A mídia seleciona, organiza e propaga as informações: o que ela apresenta é apenas uma leitura possível de um tema ou de um fato. O mundo que conhecemos - e a partir do qual refletimos - "é um mundo que nos chega editado, ou seja, ele é redesenhado num trajeto que passa por centenas, às vezes milhares de filtros até que "apareça" no rádio, na televisão e no jornal" (Baccega, 2005, p.7).

O fato da mídia veicular um número elevado de in- 
formações, ampliando as possibilidades de acesso e de propagação da informação, não garante a produção de conhecimento, que se diferencia de consumo de informação. $\mathrm{O}$ acesso e a assimilação de informações possibilitam apenas acúmulo ou soma de dados, pois a mera assimilação de informação não nos modifica, não nos transforma e não nos liberta para a reflexão, a palavra e a ação. $\mathrm{O}$ conhecimento pressupõe consciência - uso das potencialidades mentais para além da memorização e do mero registro de informação.

No mundo contemporâneo, que se caracteriza pela divulgação e circulação de informações, o saber impõese como uma necessidade, posto ser uma das principais - talvez a única - vias de desvendamento do mundo. Saber algo implica seu controle: classificar, tipificar e dissecar o objeto, de modo que seja possível organizálo, isto é, compreender sua natureza e dominar suas manifestações (Foucault, 1987). É, pois, nas relações de saber-poder que os indivíduos podem constituir-se cidadãos ou serem engessados em condições de humilhação, invisibilidade e silêncio.

\section{A nosso ver, o problema} reside no fato de que a mídia enfatiza as crises, as situações de emergência, incentivando a doação e o sentimento de solidariedade e compaixão dada uma calamidade social momentânea ou uma festividade.

No processo de transmissão de informação e de produção do conhecimento, além do elemento gerador e do meio transmissor, existe uma consciência receptora, ou seja, uma necessidade humana que confere sentido à informação. Entenda-se aqui "informação como fenômeno social [...] gerado num contexto histórico-sociocultural definido" e elemento fundante para a capacidade de "analisar situações, encontrar soluções para problemas, julgar com conhecimento de causa" (Varela, 2007, p.30).

Ter acesso à informação é o primeiro passo para a construção do conhecimento que implica a realização de operações mentais como a comparação, a análise, a hierarquização etc, de modo que seja possível estabelecer relações entre as muitas informações e chegar a sínteses ou, em outros termos, a opiniões, reflexões e tomadas de decisão. Assim, construir conhecimento pressupõe conferir sentido a informação, relacioná-la com outras, operando uma recontextualização por meio das referidas operações mentais. Para que uma informação tornese significativa, é necessário que ela altere a percepção, o entendimento e a ação do indivíduo sobre a realidade e a vida. Quanto maior o conhecimento e a condição para construí-lo, maior a capacidade de estabelecer relações e de agir de modo a interferir na realidade, quer externa ou internamente - no plano psicológico. A produção de conhecimento está, pois, intimamente relacionada à cidadania: "o saber, além de acesso a informações, exige a construção de representações internas (conhecimento) e uma prática (desempenho) que molda continuamente o conhecimento" (Varela, 2007, p.78).

Entretanto, não é toda e qualquer informação que serve para fomentar a construção de conhecimento e a ação modificadora da realidade numa perspectiva social e, portanto, cidadã. Segundo Miranda, "somente quando a informação fornecida é relevante para as necessidades dos usuários é que ela será ferramenta para o desenvolvimento" (apud Varela, 2007, p.32). Se a mídia propaga informações, ela o faz - conforme já mencionamos - segundo um recorte interessado da realidade, todavia realiza uma operação importante e necessária quando se considera a precária situação social brasileira no que se refere aos serviços de informação.

Parece haver um descompasso entre a responsabilidade da mídia de divulgar informação e a construção de conhecimento para um "saber agir sobre o mundo", condição sine qua non do conceito de cidadania, que não está contemplada na forma como a mídia opera em relação às campanhas de solidariedade. A nosso ver, o problema reside no fato de que a mídia enfatiza as crises, as situações de emergência, incentivando a doação e o sentimento de solidariedade e compaixão dada uma calamidade social momentânea ou uma festividade. Trata-se de uma ênfase espetacularizada: a operacionalização das campanhas sugere um modelo de atuação que mais chama a atenção para a existência da causa do que para a ação transformadora da sociedade. Nesse caso, há mobilização, mas não há efetiva ação, posto que os doadores não se envolvem numa prática cotidiana que vise à modificação do problema social divulgado.

A construção de conhecimento pressupõe, pois, mais que adesão a causas espetacularizadas esporadicamente: pressupõe prática e intervenção cotidianas. Essa condição ainda não é alcançada por grande parte dos brasileiros que vivem em situação econômica precária e que não têm acesso aos direitos humanos básicos e muitas vezes nem à educação: daí o lugar de relevância que a mídia assume ao divulgar informações. Certamente não cabe a ela realizar o papel social de instituições como a escola, mas cabe à mídia adequar-se à situação da sociedade brasileira, bem como responsabilizar-se por "aquilo que" e "como" divulga. Se a cidadania é 
construída pelo sujeito que se torna capaz de exercêla, são também necessárias justiça social e condições de empoderamento para que o sujeito se faça cidadão.

Ao espetacularizar a caridade, a mídia promove um esvaziamento do conceito de cidadania e uma confusão entre as noções de compromisso social e de adesão momentânea a determinadas causas. A participação de celebridades é um aspecto da espetacularização: a campanha "Natal dos Sonhos" contou com um desfile de moda realizado por celebridades para seu lançamento, um jogo de futebol com times formados por modelos, além de um desfile em carro aberto pelas principais avenidas da cidade de São Paulo para reforço de divulgação. A campanha "Criança Esperança", por sua vez, prevê um show com a participação de cantores de sucesso e de artistas do elenco da Rede Globo, tanto da equipe de dramaturgia quanto da de telejornalismo. Os exemplos são muitos e o que se revela de modo mais expressivo é o espetáculo: não se trata aqui de invalidar a realização das campanhas de solidariedade, mas de chamar a atenção para a forma como a mídia opera no sentido de engessar aquele que recebe a doação, impossibilitando-lhe alterar seu lugar nas relações de força.

No discurso midiático, as representações das minorias simbólicas estão mais próximas de uma percepção congelada destes atores do que de valores que os traduzam naquilo que compõe sua identidade. Como discurso hegemônico, a mídia fala de um lugar de poder e, como tal, apresenta em sua narrativa sedimentação e massificação de estereótipos étnico-culturais e sócio-econômicos. Esse engessamento encontra suas raízes nas práticas de saber e poder intrínsecas à discursificação da alteridade - como nos mostra Foucault nos estudos genealógicos do registro. Tendo o poder como centro do debate, pode-se dizer que a questão não pára na narração do outro sob os olhos do mesmo, mas também e sobretudo sinaliza para a precarização da condição discursiva dessas minorias simbólicas. Ou seja, além do discurso dominante determinar uma concepção de outro, ele também reforça, na cristalização das representações, sua reduzida condição discursiva na relação intrínseca entre discurso e posição na ordem econômica.

Por sua vez, a comunicação processual e contrahegemônica - realizada no nível micro das relações sociais, que tece os fios da sociabilidade e que dá corpo a fraturas nas relações de poder-saber - possibilita uma desorganização ou uma desconstrução do engessamento e da imobilidade, presentes no discurso midiático que espetaculariza a caridade. Exemplifiquemos: a Articulação do Semi-Árido Brasileiro (ASA), criada em 1999, no Recife, durante a realização da III Conferência das Partes da Convenção das Nações Unidas para o Combate à Desertificação (COP3), reúne entidades e organizações ${ }^{5}$ da sociedade civil que desenvolvem projetos de combate à desertificação na região do Semi-Árido.
Por meio de medidas simples, sem a necessidade de elevados custos, a ASA define como um de seus objetivos mobilizar e capacitar o habitante do Semi-Árido a conviver com a caatinga, retirando dela os recursos de que necessita. O Programa de Formação e Mobilização Social para a Convivência com o Semi-Árido: Um Milhão de Cisternas Rurais (P1MC) revela a concepção do trabalho da ASA: a construção de cisternas não é a finalidade última do programa, mas a fratura que se cria na compreensão estereotipada da seca e da caatinga como algo que deva ser combatido e eliminado. Diferente das ações solidárias esporádicas - envio de água para os carentes - , as cisternas alteram a situação de falta de água na região do Semi-Árido: é uma solução permanente porque promove a ação do homem local e altera seu conhecimento de si e do mundo. Há uma transformação no "saber-agir sobre o mundo", já que a intervenção é realizada numa perspectiva dos recursos locais.

Sob a perspectiva da cidadania, o empoderamento como resultado da construção de conhecimento de si e do mundo é alcançável somente quando a palavra e a ação estão integradas à produção de sentido. Para o habitante do Semi-Árido, aprender a lidar com a seca é uma forma de se tornar cidadão, posto que as cisternas são metáforas de palavra e de ação de indivíduos que podem tomar seu destino nas mãos e criar fraturas nas estruturas tradicionais de dominação política, hídrica e agrária. Importante entender que o Programa Um Milhão de Cisternas não soluciona todos os problemas da complexa realidade do Semi-Árido, mas instaura uma concepção mais humana e menos espetacular de atuação junto às minorias simbólicas.

\section{Considerações finais}

Destaquemos alguns aspectos reveladores da transformação promovida pela comunicação processual e contra-hegemônica que o referido programa contempla: o empoderamento discursivo, por meio da capacitação e mobilização das famílias, possibilita modificar as práticas cotidianas, alterando o "dizer" e o "fazer" dos envolvidos; por sua vez, a palavra e a ação materializam o processo de constituição do cidadão que poderá dizer de si e fazer para si, fora do estereótipo de carente, impossibilitado e migrante.

Ainda outro aspecto da transformação é o enraizamento que permite a fixação do homem ao Semi-Árido, dispondo de condições materiais para viver dignamente, plantando e criando animais. Importantíssimo, nesse quadro de transformações promovidas pela comunicação contra-hegemônica, é a criação de novas representações do Semi-Árido - que desestabilizam aquela já cristalizada pelo discurso hegemônico mais comumente divulgado pela mídia - e também de condições de participar da definição de políticas públicas ou, em outros termos, de "dizer não" para decisões que 
de alguma forma prejudiquem os habitantes da região. A mobilização dos agricultores do Semi-Árido, a partir da ASA, para que o Semi-Árido fique fora da área de zoneamento permitida à plantação de transgênicos, é um exemplo de participação nas decisões políticas. Agricultores locais desenvolveram técnicas para produção de algodão agro ecológico que lhes garante não só uma autonomia econômica - a Europa paga mais, inclusive, pelo algodão sem agrotóxico -, como também garante o emprego de outras famílias da região, provenientes do clube de mães e de cooperativas locais. Os agricultores sabem que a plantação transgênica implica dependência econômica e pagamento de royalties e descobriram que, dizendo "não" aos agrotóxicos e aos transgênicos, novas práticas e relações de negócio se tornaram possíveis sem o intermédio dos agentes econômicos dominantes. Ainda assim, a comercialização de produtos do Semi-Árido para a Europa viabilizou-se - fratura antes inimaginável no conjunto de linhas de força do dispositivo mercado.

Deste modo, observamos que ação e palavra, quando estimuladas, são resgatadoras do sentido mais amplo de cidadania. Se a dádiva articula o sistema de trocas e fortalece as relações sociais, ela também, no corpo da caridade, pode revelar relações de dominação, de que as minorias econômicas/simbólicas não conseguem desvencilhar-se. Neste ponto, cidadania e caridade se opõem. Fica-nos a idéia de que a emancipação social resulta de uma valorização das condições de expressão e de criação de alternativas próprias. E que, curiosamente, estas linhas de fratura ganham visibilidade e capacidade de enunciação ao lado das linhas de força, que alimentam o modelo de funcionamento do sistema econômico. Em todo este processo de empoderamento, de fortalecimento das linhas de fratura, fica claro que a comunicação desempenha um importante papel. Não aquele conduzido usualmente pela comunicação midiática, que naturaliza e banaliza representações engessadas da alteridade, mas aquela outra, contra-hegemônica, capaz de trazer à luz e fortalecer saberes locais. Aquela que gera laços, valoriza conhecimentos próprios, suscita a troca e garante a circularidade das relações solidárias e de respeito entre as diferenças $\square$ FAMEcos

\section{NOTAS}

* Trabalho apresentado ao GT "Economia Política e Políticas da Comunicação", do XVII Encontro da Compós, na UTP, em Curitiba, PR, em junho de 2008.

1 O que é típico de campanhas de grande impacto, sobretudo as televisivas, cujo apelo se concentra invariavelmente no casamento entre caridade e cidadania - casamento este que desejamos, aqui, analisar. Como exemplo, poderíamos citar as recorrentes campanhas contra a fome e a miséria em determinadas datas festivas, como Natal e Dia das Crianças. Esta espécie de conversão do agente, proporcionada pelo rito mágico da dádiva, nos faz lembrar a dinâmica do sacrifício quando se deseja garantir os ventos propícios da prosperidade e da proteção dos deuses: "que a coisa consagrada sirva de intermediário entre o sacrificante [...] e a divindade à qual o sacrifício é endereçado. $\mathrm{O}$ homem e o deus não estão em contato imediato" (Mauss \& Hubert, 2005, p.17).

2 Ao falar da 'demanda' por dons, Godelier insinua uma vertente de laicização da dádiva e aponta que a mesma se tornou, ao longo do tempo, midiática e burocrática, de modo a sofrer os impactos de uma espetacularização capaz de suplantar distâncias. Assim, "o dom tornou-se um ato que liga sujeitos abstratos" (Godelier, 2004, p.12).

3 A questão da ação que adquire valor na presença de outros humanos é tema de importância central para os estudos da cidadania. As autoras contaram, de modo significativo, com os escritos de José Moura Gonçalves Filho acerca da invisibilidade pública e da humilhação social. Para maior aprofundamento, ler também: BOSI, Ecléa. O tempo vivo da memória. São Paulo: Ateliê Editorial, 2003; assim como ARENDT, Hannah. A condição humana. São Paulo: Forense, 2007; e ainda WEIL, Simone. O enraizamento. São Paulo: Edusc, 2001.

4 Caberia aqui uma reflexão ainda que rápida sobre o sentido de "empresa cidadã". Esta apropriação da palavra cidadania e sua banalização pelo mundo das organizações privadas não poderia deixá-las mais distantes do sentido real do termo. Para que uma empresa fosse cidadã, ela precisaria ir muito além do que seu modelo de funcionamento pressupõe; ela precisaria prescindir de seus valores usualmente etnocêntricos, que tomam o ritmo e as perspectivas do outro como simbolicamente inferiores e abdicáveis. Teria, também, que conferir voz e condição de ação aos agentes sociais com que interage, em vez de buscar, muitas vezes, convencê-los de projetos que não são seus ou, pior, fazê-los crerem seus quando na verdade nunca foram. A comunicação, neste ponto, desempenha papel importante no jogo da dominação, já que muitas vezes sugere escuta onde há apenas efeito de interlocução.

5 Instituto Sertão, Fundação Grupo ESquel Brasil, ONG Diaconia, Diocese de Juazeiro-BA são alguns exemplos da variedade de entidades ou organizações da sociedade civil que integram a Articulação do Semi-Árido (ASA). Para mais informações, ver <http://www.asabrasil.org.br>. 


\section{REFERÊNCIAS}

ARENDT, Hannah. A condição humana. Rio de Janeiro: Forense Universitária, 2007.

BAUMAN, Zygmund. Globalização: as conseqüências humanas. Rio de Janeiro: Zahar, 1999.

BACCEGA, M. Aparecida. Comunicação, educação e tecnologia: interação. In: Comunicação e Educação. São Paulo, ano X, n. 1, jan/abril, 2005.

BEUTER, Simone. Cidadania Planetária: uma nova concepção socioambiental que contempla o meio ambiente como um direito humano fundamental. In: SPAREMBERGER, Raquel et al. (Org.) Direito ambiental: um olhar para a cidadania $e$ sustentabilidade planetária. Caxias do Sul: EDUCS, 2006.

BOSI, Ecléa. O Tempo vivo da memória. São Paulo: Ateliê Editorial, 2003.

BRUNI, José Carlos. Foucault: o silêncio dos sujeitos. In: SCAVONE, Lucila et al. (Org.) O legado de Foucault. São Paulo: UNESP, 2006.

CERTEAU, Michel de. A invenção do cotidiano. Petrópolis: Vozes, 1994.

DELEUZE, Gilles. Conversações. Rio de Janeiro: Ed 34, 1992.

DEMO, Pedro. Cidadania tutelada e cidadania assistida. Campinas: Autores Associados, 1995.

FOUCAULT, Michel. Resumo dos cursos do Collège de France (1970-1982). Rio de Janeiro: Zahar, 1997.

- A verdade e as formas jurídicas. Rio de Janeiro: Nau, 1999.

. Vigiar e punir: o nascimento da prisão. Petrópolis: Vozes, 1987.

. Microfísica do poder. Rio de Janeiro: Graal, 1979.

FRIGOTTO, G. Cidadania, Tecnologia e Trabalho: desafios de uma escola renovada. In: Tecnologia Educacional, v. 21, nº 107, p.4-10, 1992.

GODELIER, Maurice. O enigma do dom. Rio de Janeiro: Civilização Brasileira, 2001.

GONÇALVES FILHO, José Moura. A invisibilidade pública (prefácio). In: COSTA, Fernando Braga da. Homens invisíveis. São Paulo: Globo, 2004.

.Humilhação Social: humilhação política. In: SOUZA, Beatriz. Orientação à queixa escolar. São Paulo: Casa do Psicólogo, 2007.

.Olhar e Memória. In: NOVAES, Adauto. $O$ Olhar. São Paulo: Companhia das Letras, 1988.

Cultura e formação: notas marginais. In: PATTO, Maria Helena \& FRAYZE-PEREIRA, João. Pensamento cruel: humanidades e ciências humanas. São Paulo: Casa do Psicólogo, 2007.

LEROY, Jean-Pierre \& PACHECO, Maria Emília Lisboa. Como fazer com que o acesso aos recursos genéticos da biodiversidade brasileira seja feito de forma ambientalmente sustentável e seus benefícios repartidos de forma socialmente justa? In: CAMARGO, Aspásia et al. (Orgs.). Meio ambiente Brasil: avanços e obstáculos pós-Rio-92. São Paulo: ISA, 2004.

MAUSS, Marcel. Sociologia e antropologia. São Paulo: Cosac\&Naify, 2003.

OLIVEIRA JUNIOR, José Alcebíades de. Teoria jurídica e novos direitos. Rio de Janeiro: Lumen Júris, 2000.

SANTOS, Boaventura de Sousa. A gramática do tempo: para uma nova cultura política. Porto: Afrontamento, 2006.

- Renovar a teoria crítica e reinventar a emancipação social. São Paulo: Boitempo, 2007.

VARELA, Ainda. Informação e construção da cidadania. Brasília: Thesaurus, 2007.

WEIL, Simone. O enraizamento. São Paulo: EDUSC, 2001. 